\title{
PATTERN OF MARKETING AND DISPOSAL OF POTATO IN LOWER BRAHMAPUTRA VALLEY ZONE OF ASSAM
}

\section{SANGITA BORAH}

Faculty Associate, Assam Rajiv Gandhi University of Cooperative Management, Sivasagar, Assam, India

Potato is a major food crop, has emerged as fourth most important food crop in India after rice, wheat and maize. Potato (SolanumtuberosumL.) popularly known as 'The king of vegetables', It has been observed that during the present trend of diversification from cereals to horticultural crops, shift from wheat / barley to potato has taken place especially owing to higher returns and adaptable to a wide variety of farming systems. It is believed that potato prices are driven by supply and demand by distinctive seasonal trends. Potato prices decline with the increase in supply, and vice versa.

From the study conducted during the period 2015-16 about potato marketing and disposal pattern in LBVZ indicated that quantum taken to the specified market increases from size group I (78.08 q) to size group III (176 q) farmers. It was also observed that the quantity of potato sold in specified market was more than the quantity sold at retail markets in all the size groups of farmers in the zone. Cost of production of potato increases from size group I (Rs 25343.90) to size group III (Rs 58366.00) farmers. Margin per quintals of potato sold was observed to be highest for size group III (Rs 259.35) followed by size group II (Rs 244.91) and size group I (Rs 216.14) respectively. Study on marketing Channels reflected that the producer's share in consumer's rupee was 72.83 per cent in Channel I, 63.66 percent in Channel II and 55.00 percent in Channel III respectively. Likewise, retailer's share in consumer's rupee was 12.25 per cent in Channel I, 7.96 percent in Channel II and 13.06 percent in Channel III for the LBVZ of Assam.
\end{abstract}

KEYWORDS: Potato Marketing, Brahmaputra Valley Zone of Assam, Margin of Marketed Potato \& Marketing Channels

Received: Aug 07, 2017; Accepted: Aug 24, 2017; Published: Sep 19, 2017; Paper Id.: IJASROCT201727

\section{INTRODUCTION}

Potato is a major food crop emerged as the fourth most important food crop in India after rice, wheat and maize. It has been observed that during the present trend of diversification from cereals to horticultural crops, shift from wheat / barley to potato has taken place, especially owing to higher returns and adaptable to a wide variety of farming systems. Being a short duration crop, it produces more quantity of dry matter, edible energy and edible protein in lesser duration of time than cereals like rice and wheat. With its short vegetative cycle and high yields within 100 days, it fits well into double cropping systems with rice, and is also suitable for intercropping with maize and soybeans. India's potato production has seen a phenomenal increase since the 1950s, mainly due to strong demand from the processing industry and remunerative returns. Potato is one of the main commercial crops in India. It is believed that potato prices are driven by supply and demand by distinctive seasonal trends. Potato prices decline with the increase in supply, and vice versa. It is a wholesome food and consumed by all sections of the people. It is also becoming an important source of rural employment and income for a growing population. India is the second largest producer of potato in the world after China and both the countries together contribute nearly one third of the global potato production. (Vision 2050, 2015) 
Potato is an important crop in the North Eastern Region in India, especially the hilly tracts, where the crop is grown under rain fed conditions. The crop is grown throughout the year in one or the other part of the North Eastern region contributing about 10 per cent of the total area under potato in the country. The said crop forms an important part of prevailing cropping systems as well as the dietary food habits of the people of the region. Potato is one of the most important and widely cultivated vegetable crops of Assam and ranks fourth in terms of acreage under individual crop in the state.

Marketing can be defined as the commercial functions involved in transferring goods from producer to consumer. Marketing assumes special significance with regard to profitability of any agricultural commodity in a given agriculture production situation. This is more so with regard to perishable and semi perishable as well as bulky agricultural commodities. The said crop forms an important part of prevailing cropping systems as well as the dietary food habits of the people of the region. The semi perishable and bulkiness are the innate characteristic of potato that causes problems in its market. Marketing and storage were also identified as important weaknesses of potato production in India. Facilities for storage, processing and marketing are deficient for perishable commodities as a technological constraint for agricultural development of north eastern region of India. Owing to the highlighted weaknesses, the rural marketing in the region is confined primarily to unorganized sector with domination of private traders.

The present paper examines the potato marketing and disposable pattern in the Lower Brahmaputra Valley Zone of Assam

\section{METHODOLOGY}

The study was conducted in the Lower Brahmaputra Valley Zone of Assam which comprises districts Dhubri, Kokrajhar, Goalpara, Barpteta, Nalbari, Chirang, Baska, Kamrup rural and Metro. Multistage Stratified Proportionate Random sampling technique was used to select the commercial potato growers of the study area. In the first stage, two development blocks from each district of Lower Brahmaputra Valley Zones were selected. In the second stage, two AEO circles were selected randomly from the list of AEO circles of the blocks. The villages under each AEO circle were listed and six villages- three from each AEO circle were selected randomly. The farmers of the selected villages were listed and they were categorized under three categories, viz. Marginal (Size Group I, below 1 ha) small (Size Group II, 1.00 to 2.00 ha), semi medium (Size Group III, 2.00 to 4.00 ha) based on their operational holding. In the sample households no farms belonging to Medium and large sizes were available. Finally, 10 percent of samples from each size group were selected randomly from each zone without replacement for detailed investigation. This formed a random sample of 480 members comprising of 200 marginal farmers, 148 small and 132 semi medium size group of farms.

The primary data for the year 2015-16 were collected with the help of a specially designed pre tested schedule and questionnaire through personal interview. Secondary data were collected from various sources like Department of Agriculture, Offices of Agricultural Marketing Officers, Assam State Agricultural Marketing Board, Directorate of Economics and Statistics and various published and unpublished sources.

\section{Cost of Cultivation}

The cost of cultivation has been worked out by using the standard cost concepts as defined and used in economies of farm management for estimation of the cost of cultivation as under. 
Variable cost $=$ All costs incurred in cash or kind on all material inputs, hired human labour, interest on working capital.

Cost $\mathrm{A}_{1}=$ All variable costs + other miscellaneous charges.

Cost $\mathrm{A}_{2}=$ Cost $\mathrm{A}_{1}+$ Rental value of leased in the land

Cost $\mathrm{B}=$ Cost $\mathrm{A}_{2}+$ Rental value of own land

Cost $\mathrm{C}=$ Cost $\mathrm{B}+$ Imputed value of family labour.

The gross income, income over variable cost, net income, farm business income and family labour income have been worked out as follows

\section{Gross Income}

\section{Returns}

- Gross income $=$ the gross income was computed by multiplying the output or quantity of produced by price.

- Farm Business income $=$ Farm business income was calculated by deducting Cost $\mathrm{A}_{2}$ from gross income

- Family labour income = It was computed by deducting Cost B from gross income

- Net income $=$ Net income was calculated by deducting Cost $\mathrm{C}$ from gross income.

\section{Marketable Surplus}

The marketable surplus of farm product can be expressed through the following identity

$$
\mathrm{M}=\mathrm{Q}-\mathrm{C}
$$

Where, $\mathrm{M}$ is marketable surplus, $\mathrm{Q}$ is output and $\mathrm{C}$ is total on farm consumption (utilisation) of output.

Per farm marketed surplus of potato was estimated as the sum total of potato actually sold by the individual producer, farmer deflated it by the total no of sample producer farmers during the study period. Hence, the per farm marketed surplus of potato can be expressed through the following identity

$$
\mathrm{MS}=\sum \mathrm{Q} / \mathrm{N}
$$

Where, MS is per farm marketed surplus of potato, $\mathrm{Q}$ is quantity of potato produce during a particular production period and marketing year/ season, and $\mathrm{N}$ is the total number of sample growers.

\section{FINDINGS AND DISCUSSIONS}

The average land holding size among the sampled farmers of Lower Brahmaputra Valley Zone of Assam was found to be 1.34 ha and average land under potato cultivation was observed to be 0.56 ha during the study period.

\section{Disposal of Marketed Potato of the Sample Farmers of LBVZ}

It was observed from the Table1 that quantum taken to the specified market increases from size group I (78.08 q) to size group III ( 176 q) farmers. It was also observed that the quantity of potato sold in specified market was more than the quantity sold at retail markets in all the size groups of farmers in the zone. The dispersal pattern of potato was found to increase with increase size groups of farmers. But in the other hand wastage in marketing was found to be highest in size 
group I farmers $(0.87 \mathrm{q})$ and lowest in size group III ( $0.33 \mathrm{q})$ farmers. This could be attributed owing to better management practices followed by the large farmer which brings less wastage in marketing of potato in the zone.

Table 1: Disposal of Marketed Potato of the sample Farmers of LBVZ

\begin{tabular}{|l|l|l|l|l|}
\hline \multicolumn{1}{|c|}{ Particulars } & \multicolumn{1}{|c|}{ Group I } & \multicolumn{1}{c|}{ Group II } & \multicolumn{1}{c|}{ Group III } & Pooled \\
\hline Disposal (Qtls) & & & & \\
\hline Quantum taken to the Specified Market (Marketed) & 78.08 & 125.49 & 176 & 121.45 \\
\hline Quantity Sold in Specified Market & 65.26 & 111.25 & 154.80 & 105.37 \\
\hline Quantity sold in (elsewhere) retail market (Direct marketing) & 12.82 & 14.24 & 21.20 & 16.08 \\
\hline Any other Disposal (Wastage in marketing etc.) & 0.87 & 0.52 & 0.33 & 0.57 \\
\hline Total Quantum Sold & 77.21 & 124.97 & 175.67 & 120.88 \\
\hline
\end{tabular}

\title{
Margin of Marketed Product of the Sample Farmers of LBVZ
}

Table 2 reflected that farmers cost of production of potato which exhibited an increasing trend from size group I (Rs. 25343.90) to size group III (Rs. 58366.00) farmers of LBVZ. With the increase in size groups of farmer margin of farmers also increases from size group I (Rs. 16688.66) to size group III (Rs. 45559.60). Margin per quintals of potato sold was observed to be directly related with size group of farms highest being in size group III (Rs. 259.35) followed by size group II (Rs. 244.91) and size group I (Rs. 216.14) respectively. However, studies conducted other did not consider size categories in case of margin of marketed product of the sample farmers in case of potato in the Assam.

Table 2: Margin of Marketed Product of the Sample Farmers of LBVZ

\begin{tabular}{|l|c|c|c|c|}
\hline \multicolumn{1}{|c|}{ Particulars } & Group I & Group II & Group III & Pooled \\
\hline Total Quantum Sold (qtls) & 77.21 & 124.97 & 175.67 & 120.88 \\
\hline Average Returns (Rs.) & & & & \\
\hline Total Sales & 42032.56 & 71831.90 & 103925.60 & 68844.60 \\
\hline Total Farmers Costs & 25343.90 & 41225.84 & 58366.00 & 39402.76 \\
\hline Margin of The Farmer (Rs.) & 16688.66 & 30606.06 & 45559.60 & 29441.84 \\
\hline Margin per Quintal Sold (Rs.) & 216.14 & 244.91 & 259.35 & 243.56 \\
\hline
\end{tabular}

\section{Marketing Channels}

Marketing channels are the routes through which the surplus products move from the hands of producers to the hand of ultimate consumers. It involves various middlemen while facilitate the flow of goods and services from the points of production to the points of ultimate consumption. The length of marketing channels varies from commodity to commodity, depending upon the quantity to be moved, the nature of consumer demand, degree of regional specialization in production, etc. The study of marketing channels is essential to know the efficiency of marketing system.

The traditional channels for potato were identified based on market survey, reports from the growers and discussion with the officials from the Agriculture Department's officials in the present study.

\author{
Channel - I: Producer-> Retailer-> Consumer \\ Channel -II: Producer-> Commission Agent-> Wholesaler-> Retailer-> Consumer \\ Channel -III: Producer-> Commission Agent-> Merchant wholesaler-> Wholesaler -> Retailer -> Consumer
}

\section{Price Spread}

The price spread refers to the difference between the price received by the producers and the price paid by the consumers. It was observed that there were wide variations of the price received by the growers and the price paid by the 
ultimate consumer. The market functionaries are, to perform a number of functions which involve a variety of costs in assembling the marketable produce from a large number of growers scattered over a wide area.

Price Spread of Potato in Cannel I in LVBZ of Assam

The price spread of potato in Channel-I in LBVZ was worked out and presented in Table 3. It was seen from the Table that the producer's share in consumer's rupee was 72.83 per cent in the zone. From the calculation, it was also reflected that excluding the marketing cost, retailer's share in consumer's rupee was 12.25 per cent.

Table 3: Table Price Spread of Potato in Traditional Marketing Channel - I in LBVZ

(Channel I: Producer - Retailer - Consumer)

\begin{tabular}{|l|c|c|c|}
\hline \multicolumn{1}{|c|}{$\begin{array}{c}\text { Items of Cost and Market } \\
\text { Functionaries }\end{array}$} & $\begin{array}{c}\text { Average Price } \\
\text { (Rs. per q.) }\end{array}$ & $\begin{array}{c}\text { Margin at } \\
\text { Different Level }\end{array}$ & $\begin{array}{c}\text { Percentage } \\
\text { Share }\end{array}$ \\
\hline $\begin{array}{l}\text { Net Price to the Producer } \\
\text { (Retailer's purchase price) }\end{array}$ & 437 & 437 & 72.83 \\
\hline Producer's Marketing Cost (Rs.) & 45.21 & 45.21 & 7.53 \\
\hline Labour Charge (loading \& Unloading) & 8.00 & 8.00 & 1.33 \\
\hline Transportation Cost & 23.00 & 23.00 & 3.83 \\
\hline Weighting Cost & 5.00 & 5.00 & 0.83 \\
\hline Market Fees & 2.00 & 2.00 & 0.33 \\
\hline Wastage & 7.21 & 7.21 & 1.20 \\
\hline $\begin{array}{l}\text { Retailer's purchase price } \\
\text { (Producer's Selling Price) }\end{array}$ & 482.21 & - & - \\
\hline Retailer's Marketing Cost & 44.30 & 44.30 & 7.38 \\
\hline Labour Charge (loading \& Unloading) & 8.00 & 8.00 & 1.33 \\
\hline Transportation Cost & 13.00 & 13.00 & 2.16 \\
\hline Storage cost & 5.00 & 5.00 & 0.83 \\
\hline Market Fees & 2.00 & 2.00 & 0.33 \\
\hline Wastage & 11.30 & 11.30 & 1.88 \\
\hline Other marketing expenses & 5.00 & 5.00 & 0.83 \\
\hline $\begin{array}{l}\text { Retailer's Selling Price } \\
\text { (i.e. Consumer's purchase price) }\end{array}$ & 600.00 & 73.49 & 12.25 \\
\hline \multicolumn{1}{|c|}{ Total } & & 600.00 & 100.00 \\
\hline
\end{tabular}

Price Spread of Potato in Traditional Marketing Channel - II in LBVZ

It was observed from the Table 4 that producer's share in consumer's rupee was 63.66 per cent. Likewise, commission agents share in consumer's rupee was 7.33 per cent excluding the marketing cost. Similarly, Wholesaler's share in consumer's rupee was 5.83 per cent and retailer's share in consumer's rupee was 7.96 per cent excluding the marketing cost.

\section{Price Spread of Potato in Traditional Marketing Channel - III in LBVZ}

It was seen from the Table 5 that the producer's share in consumer's rupee was 55.00 per cent. Excluding the marketing cost, wholesaler's share in consumer's rupee was 4.96 per cent. Similarly merchant wholesaler's share in consumer's rupee was 2.75 per cent, wholesaler's share in consumer's rupee was 6.45 per cent and retailer's share in consumer's rupee was 13.06 per cent respectively. 
Table 4: Price Spread of Potato in Traditional Marketing Channel - II in LBVZ (Channel II: Producer - Commission Agent - Wholesaler - Retailer - Consumer)

\begin{tabular}{|l|c|c|c|}
\hline Items of Cost and Market Functionaries & $\begin{array}{c}\text { Average Price } \\
\text { (Rs. per q.) }\end{array}$ & $\begin{array}{c}\text { Margin at } \\
\text { Different Level }\end{array}$ & $\begin{array}{c}\text { Percentage } \\
\text { Share }\end{array}$ \\
\hline $\begin{array}{l}\text { Net Price to the Producer } \\
\text { (Commission Agent's purchase price) }\end{array}$ & 382.00 & 382.00 & 63.66 \\
\hline Commission Agent's Marketing Cost & 22.00 & 22.00 & 3.66 \\
\hline Weighting Cost & 5.00 & 5.00 & 0.83 \\
\hline Storage cost & 5.00 & 5.00 & 0.83 \\
\hline Wastage & 4.20 & 4.20 & 0.70 \\
\hline Miscellaneous Expenditure (bag etc.) & 7.80 & 7.80 & 1.30 \\
\hline $\begin{array}{l}\text { Commission Agent's selling price } \\
\text { (i.e. Wholesaler's purchase price) }\end{array}$ & 448.00 & 44.00 & 7.33 \\
\hline Wholesaler's Marketing Cost & 27.00 & 27.00 & 4.50 \\
\hline Labour Charge (loading \& Unloading) & 4.00 & 4.00 & 0.66 \\
\hline Transportation Cost & 4.20 & 4.20 & 0.70 \\
\hline Weighting Cost & 5.00 & 5.00 & 0.83 \\
\hline Storage cost & 2.00 & 2.00 & 0.33 \\
\hline Market Fees & 3.60 & 3.60 & 0.60 \\
\hline Wastage & 8.20 & 8.20 & 1.36 \\
\hline $\begin{array}{l}\text { Wholesaler's Selling Price } \\
\text { (i.e. Retailer's purchase price) }\end{array}$ & 510.00 & 35.00 & 5.83 \\
\hline Retailer's Marketing Cost & 42.25 & 42.25 & 7.04 \\
\hline Labour Charge (loading \& Unloading) & 4.00 & 4.00 & 0.66 \\
\hline Transportation Cost & 10.00 & 10.00 & 1.66 \\
\hline Storage cost & 5.00 & 5.00 & 0.83 \\
\hline Market Fees & 6.00 & 6.00 & 1.00 \\
\hline Wastage & 12.25 & 12.25 & 2.04 \\
\hline Other marketing expenses & 5.00 & 5.00 & 0.83 \\
\hline $\begin{array}{l}\text { Retailer's Selling Price } \\
\text { (i.e Consumer's purchase price) }\end{array}$ & 600 & 47.75 & 7.96 \\
\hline Total & & 600.00 & 100.00 \\
\hline & & & \\
\hline
\end{tabular}

Table 5: Price Spread of Potato in Traditional Marketing Channel - III in LBVZ

(Channel III: Producer - Commission Agent - Merchant Wholesaler - Wholesaler - Retailer - Consumer)

\begin{tabular}{|l|c|c|c|}
\hline \multicolumn{1}{|c|}{ Items of Cost and Market Functionaries } & $\begin{array}{c}\text { Average Price } \\
\text { (Rs. per q.) }\end{array}$ & $\begin{array}{c}\text { Margin at } \\
\text { Different Level }\end{array}$ & $\begin{array}{c}\text { Percentage } \\
\text { Share }\end{array}$ \\
\hline $\begin{array}{l}\text { Net Price to the Producer } \\
\text { (Pre-harvest Contractor/ Wholesaler's purchase price) }\end{array}$ & 330 & 330 & 55.00 \\
\hline Pre-harvest Contractor/Wholesaler's Marketing Cost & 20.20 & 20.20 & 3.36 \\
\hline Labour Charge (loading \& Unloading) & 3.00 & 3.00 & 0.50 \\
\hline Transportation Cost & 5.00 & 5.00 & 0.83 \\
\hline Weighting Cost & 5.00 & 5.00 & 0.83 \\
\hline Storage Cost & 3.00 & 3.00 & 0.50 \\
\hline Market Fees & 2.50 & 2.50 & 0.41 \\
\hline Wastage & 1.70 & 1.70 & 0.28 \\
\hline $\begin{array}{l}\text { Pre-harvest Contractor/Wholesaler's selling price (i.e. } \\
\text { Merchant wholesaler's purchase price) }\end{array}$ & 380 & 29.80 & 4.96 \\
\hline Merchant wholesaler's Marketing Cost & 23.50 & 23.50 & 3.91 \\
\hline Labour Charge (loading \& Unloading) & 3.00 & 3.00 & 0.50 \\
\hline Transportation Cost & 5.00 & 5.00 & 0.83 \\
\hline Weighing cost & 5.00 & 5.00 & 0.83 \\
\hline Storage cost & 3.00 & 3.00 & 0.50 \\
\hline
\end{tabular}




\begin{tabular}{|l|c|c|c|}
\hline Market Fees & 2.50 & 2.50 & 0.41 \\
\hline Wastage & 5.00 & 5.00 & 0.83 \\
\hline $\begin{array}{l}\text { Merchant wholesaler's Selling Price } \\
\text { (i.e. wholesaler's purchase price) }\end{array}$ & 420 & 16.50 & 2.75 \\
\hline Wholesaler's marketing cost & 19.30 & 19.30 & 3.21 \\
\hline Labour Charge (loading \& Unloading) & 3.00 & 3.00 & 0.50 \\
\hline Transportation Cost & 4.00 & 4.00 & 0.66 \\
\hline Storage cost & 3.00 & 3.00 & 0.50 \\
\hline Market Fees & 2.50 & 2.50 & 0.41 \\
\hline Wastage & 6.80 & 6.80 & 1.13 \\
\hline $\begin{array}{l}\text { Wholesaler's selling price } \\
\text { (i.e. Retailer's purchase price) }\end{array}$ & 478 & 38.70 & 6.45 \\
\hline Retailer's marketing cost & 43.60 & 43.60 & 7.26 \\
\hline Labour Charge (loading \& Unloading) & 4.00 & 4.00 & 0.66 \\
\hline Transportation Cost & 11.20 & 11.20 & 1.86 \\
\hline Storage cost & 6.00 & 6.00 & 1.00 \\
\hline Market Fees & 5.20 & 5.20 & 0.86 \\
\hline Wastage & 12.20 & 12.20 & 2.03 \\
\hline Other marketing expenses & 5.00 & 5.00 & 0.83 \\
\hline $\begin{array}{l}\text { Retailer's selling price } \\
\text { (i.e. Consumer's purchase price) }\end{array}$ & 600.00 & 78.40 & 13.06 \\
\hline Total & & 600.00 & 100.00 \\
\hline
\end{tabular}

\section{CONCLUSIONS AND POLICY IMPLICATIONS}

The results obtained from the present study to analyze the markets and disposable pattern of Potato in Lower Brahmaputra Valley Zone of Assam reflected that average land holding was found to be 1.34 ha and average land under potato cultivation was observed to be 0.56 ha among the selected farmers during the study period. The dispersal pattern of potato was found to have increased with increase size groups of farmers. With increases in size of the farms margin of farmers also increases from size group I (Rs 16688.66) to size group III (Rs 45559.60). Margin per quintals of potato sold was observed to be highest for size group III (Rs 259.35) followed by size group II (Rs 244.91) and size group I (Rs 216.14) respectively. The producer's share in consumer's rupee was 72.83 per cent in Channel I, 63.66 percent in Channel II and 55.00 percent in Channel III respectively. Likewise, retailer's share in consumer's rupee was 12.25 per cent in Channel I, 7.96 percent in Channel II and 13.06 percent in Channel III for the LBVZ of Assam. Potato in Lower Brahmaputra Valley Zone of Assam could be of immense use in prescribing policy measures to promote the acreage under the potato crop which leads to increase disposable pattern and marketing of the crop in the zone.

\section{The Main Policy Implications Include}

- The study revealed that, with an increase in the relative price of potato, farmers in all the selected districts tended to increase the production of the crop mainly by bringing more area under its cultivation. Hence, in order to further enhance the production of potato, the on-going price policy should be directed towards assuring appropriate enumerative price to the potato producers of the state.

- The study also revealed that by providing high quality seeds to the framers the productivity of potato can increase in the Brahmaputra Valley Zone of Assam. 
- The potato marketing that is primarily in the hands of middlemen or assemblers in the region need to be organized by potato farmers as the main stakeholders.

- Focusing attention on creating number of storage and marketing facilities, providing incentives for entrepreneurs for potato marketing would on one hand ensure a better profit margin for farmers, while on the other, would encourage farmers to achieve a higher potato production and productivity figures in the region.

\section{REFERENCES}

1. Das, M. and EzekieL, R. (2007). Prospects of the processed Potato products in Patna, India. Asian J. Hort. 2(2): $305-308$.

2. Sah, A and et al (2011). Potato Marketing in North East Region of India: A Diagnostic Study. Journal of Community Mobilization and Sustainable Development. 6(2):194-201

3. Kakaty, G and Borah D. (2011). "Impact of emerging marketing channels in Agriculture -Benefit to producer-sellers and Marketing costs and margins of Orange and Potato in Assam”. Agro-Economic Research Centre for North East India, Jorhat, study no-139.

4. Elhori A.I.S.; Shaddi, E.H.; Elrasheed, M.M.M. and Fadl Elmola, F.Y. (2013). "Economics analysis of potato production in Dongola locality - Sudan”. International J. Agri. Sci. 3(7): 577-583.

5. Directorate of Economics and Statistics, Assam (2013): State / District Wise Area, Production, Price and Value of Ten Major Crops in Assam from 2003-04 To 2012-13.

6. DEKA, K.C and et al (2014). "Constraints in potato cultivation in Assam: Farmers' experiences”. International Journal of Agricultural Sciences. 10 (2): 488-492

7. Raju Mandal (2014). “Cropping Pattern Choice and Risk Mitigation in Flood Affected Agriculture: A Study of Assam Plains, India”. SHSU Economics \& Intl. Business Working Paper No. 14-03

8. Central Potato Research Institute (2015): Vision 2050 